\title{
Szentmiklóssy-Szabó Boglárka': Gondolatok a gyermekkorú tanú kihallgatásának befolyásolhatóságáról
}

Debreceni Jogi Mühely, 2011. évi (VIII. évfolyam) 4. szám (2011. október) 30-34.

„A gyerekek sok mindent tudnak, néha a legfurcsább dolgokkal is tisztában vannak.

A gyerekeknek nagyon jó érzékük van.

Sokat látnak, sokat megértenek, ha ritkán is beszélnek róla.

Sokat tudnak, amit a felnöttek nem vesznek észre."

(Agatha Christie)

A jelenleg hatályos büntetőeljárásról szóló 1998. évi XIX. törvény (a továbbiakban: Be.) nem tesz különbséget a kihallgatható tanúk között. A törvény ugyanúgy lehetőséget ad az aggastyán és a 14. életévét be nem töltött gyermek kihallgatására is.

A Be. 68. § (2) bekezdése alapján a kiskorú idézéséről a gondozóját azzal a felhívással kell értesíteni, hogy a megjelenéséről gondoskodjék. A törvény speciális szabályként írja elö, ha a kiskorú a tizennegyedik életévét nem töltötte be, őt gondozója útján kell idézni, illetve értesíteni. A kiskorú idézését és értesítését a törvényes képviselöjével is közölni kell, kivéve, ha a törvényes képviselö és a gondozó azonos személy.

A Be. a továbbiakban azonban már speciális szabályozást ad a tizennegyedik életévét be nem töltött személy esetén, melyet a 86 . §-a tartalmaz. E szerint ezen személy tanúként csak akkor hallgatható ki, ha a vallomásától várható bizonyíték mással nem pótolható. Kihallgatása alkalmával jelen lehet törvényes képviselője és gondozója, azonban ha közöttük érdekellentét van, akkor ezt a jogot a gyámhatóság gyakorolja. Ezek a szabályok a tanú érdekeinek védelmét szolgálják, különösen az érdekellentét esetén a gyámhatóság jelenléte, hiszen ezáltal teljes körü garanciális biztosítékot ad a tanú vallomásának bizonyítékként történő felhasználásához.

Szükségesnek tartom külön kiemelni, hogy ezen jogszabályi rendelkezés alapján a kihallgatása esetén a hamis tanúzás következményeire való figyelmeztetést mellőzni kell ${ }^{2}$.

Mi lehet ennek az oka? A gyermekek fejlődésének ismerete szükséges ahhoz, hogy a gyermekektöl megfelelő információhoz lehessen jutni. Más és más a kapott információ pontossága egy korai gyermekkorban, kisiskoláskorban, iskoláskorban és serdülőkorban lévő gyermeknél. Aki tisztában van a különböző fejlödési szakaszokkal, jobban meg tudja ítélni, hogy bizonyos korú gyermek megértette-e a kérdéseket, és hogy sikeresen tudja-e közölni a gondolatait és érzéseit. ${ }^{3}$ Pont ezek a különböző fejlődési szakaszok indokolják azt, hogy a gyermekkorú tanút miért nem kell kioktatni a hamis tanúzás törvényes következményeire. A válasz pedig egyszerü, azon túlmenően, hogy életkoruknál fogva nem lehetnek büncselekmény elkövetöi: nincsenek még olyan fejlettségi szinten, hogy teljes egészében felfogják ennek jelentését és jelentőségét, illetve az életkori sajátosságokat is figyelembe véve reális alapja sincs.

Vizsgálni kell azt is, hogy a kihallgatásuk alkalmával mennyiben megbízhatóak vallomásaik. Fel lehet-e állítani egy korhatári szintet, amin belül kimondhatjuk, hogy az általuk elmondottak már olyan kellö megalapozottságúak, hogy azt a bíróság kétséget kizáró bizonyítékként tudja elfogadni. Kiemelendő, hogy a 14. életévét be nem töltött személy tanúkénti kihallgatásának törvényi lehetőségéről szóló Bkv. 68. sem határozza meg, hogy mely az a legkisebb életkor, melytől a gyermekkorú tanú már kihallgatható.

Mint, ahogy az Bányai-Dredán Dóra pszichológus előadásában is elhangzott, az éremnek két oldala van.

„Egyrészt szem előtt kell tartanunk, hogy 3 éves kortól a gyerekek képesek valódi hazugságok kitalálására. Valamint figyelembe kell vennünk, hogy a válások száma nő, ami a szülők között feszültséget eredményez, a gyermeket pedig egy lojalitáskonfliktusba helyezi. Ilyenkor a gyerekek gyakrabban hazudnak. Másrészt azonban még a 4 évesek is megbízhatóan tanúskodnak, ha 
megfelelő módon kérdezik ki öket. A kérdésre adott választ tehát mindenképpen árnyalni kell.

Már iskoláskor előtti gyerekek is pontos szabad felidézésre képesek, és kora serdülőkorig (11-12 év) növekvő teljesítményt mutatnak, ekkorra érik el a felnőttkorra jellemző eredményeket. A nyitott kérdések és a felismerés, mint kérdezési technikák több részlet felidézést teszik lehetővé, mint a szabad felidézés, bár a részletek kevésbé pontosak. A szabad felidézéshez képest a nyitott végü kérdésekkel nyert információk pontossága 6-8 éves korban már közelít a felnőttek válaszának pontosságához. A leghasznosabb, ha a szabad felidézés megelözi a nyitott végü kérdések (pl. Milyen színü pulcsi volt rajta), melyek általános természetüek és nem specifikusak (pl. Fekete pulcsi volt rajta?). Ez utóbbi zárt végü kérdésekre szuggesztibilisek, a gyermekek - minél kisebbek annál inkább - hajlamosak igenlő választ adni ezekre, hiszen a felnőtt úgyis jobban tudja, mint ők, meg akarnak felelni a feltételezett elvárásainak."4

Ebből is látszik, hogy a befolyásolás kérdéskörét nagyban megalapozzák a feltett kérdések minősége és mikéntje, a kérdezés technikája.

Tényleges kérdésként vetődhet fel, hogy mi az a legalacsonyabb életkor melytől kihallgatható a gyermekkorú tanú. Véleményem szerint ezt nem lehet meghatározni, hiszen lehet a gyermek fejlettebb az életkoránál, feltétele álláspontom szerint kihallgatásuknak, hogy megértsék a hozzájuk intézett kérdéseket és rendelkezzenek olyan megfelelő szókinccsel mellyel ki tudják magukat fejezni a megfelelő módon. Azonban, ha ez nincs meg, úgy célszerütlen kihallgatásuk, hiszen válaszaikban a védelem mindenképpen fog találni támadható felületet.

Természetesen el lehet arról gondolkodni, hogy húzható-e egy bizonyos életkori határ e tekintetben. Ha igen, figyelembe kell vennünk a gyermek biológiai és szellemi fejlettségét.

A gyermekek életkori sajátosságaival kapcsolatosan ${ }^{5}$ többféle elképzelés és tanulmány is született az elmúlt időszakban, ekként:

„Már kétéves gyerekek is képesek visszaemlékezni megtörtént eseményekre viszonylag hosszú időn keresztül, föként ha volt valamiféle elözetes tudásuk is a történtekre vonatkozóan. Hároméves kor után a gyerekeknek már megvan a képességük, hogy hozzávetőlegesen pontos és teljes tanúvallomást tegyenek, ha a meghallgatásuk előtt vagy annak során nem próbálják befolyásolni őket félrevezető információkkal vagy szuggesztív kérdésekkel." 6

„A 6 és 10 év közötti gyermek éles megfigyelő képességgel rendelkezik a részjelenségeket illetően és megfigyeléseit pontosan megtartja emlékezetében. A jelenségek összefüggéseit azonban nem képes felismerni és kifejezni. Ezért helyes, ha a kihallgató az ilyen korú gyermekeket a részjelenségekre vonatkozóan kérdezi ki. Az így kihallgatott 6 és 10 év közötti gyermekek igen jó tanúk lehetnek, ha vallomásukat minden befolyásoltságtól mentesen teszik meg, azaz kevésbé hatnak náluk szubjektív tényezők, ellenállóbbak is a befolyásolással szemben. Nagyon fontos azonban kiemelni, hogy erőteljes befolyásolás hatására bármelyik gyereket rá lehet venni, hogy ne az igazságnak megfelelő vallomást tegyen."

„A 10 és 14 év közötti gyermek már a valóság megragadására és a jelenségek összefüggéseinek kifejezésére törekszik, ezen kívül ösztönösen szintén ellenáll a befolyásolásnak. Értelmes és jó kifejező készséggel rendelkező ilyen korú gyermek általában ideális tanú lehet. Ez a korosztály azonban hajlamos arra, hogy az észlelt valóságelemekbe irreális elképzeléseket vegyítsen, és előfordul, nem képes a valóságos és a képzelt elemek szétválasztására."8

A Be. a speciális szabályozása keretében a vádirat benyújtását megelőzően a nyomozási bíró feladatává teszi a gyermekkorú tanú kihallgatását ügyész indítványára, de csak abban az esetben, ha megalapozottan feltehető, hogy a tárgyaláson történő kihallgatása a fejlődését károsan befolyásolná. A kihallgatást a törvényes képviselő, a gondozó és a tanú érdekében eljáró ügyvéd kedvezményezheti az ügyésznél. ${ }^{9}$

Azonban mit is jelent ez? Ténylegesen kik lehetnek jelen a gyermekkorú tanú kihallgatása során? Tekintettel arra, hogy a Be. eleve szük körben húzza meg a határt az ülésen jelenlévők körében, ezen személyek köre eléggé korlátozott. A Be. 213. § (3) bekezdése ad erről jogi szabályozást, visszautalva a szakaszhely (2) bekezdésében foglaltakra. Vagyis ezek a személyek a következőek: a 
nyomozási bíró, a jegyzőkönyvvezető, ügyész, a tanú érdekében eljáró ügyvéd, valamint a gyermekkorú tanú törvényes képviselöje és gondozója.

Hogy zajlik egy ilyen meghallgatás?! Gondoljunk bele, hogy a tizennégy év alatti gyermek életében - minden bizonnyal - először jár a bíróság épületében. Már ez is egyfajta szorongásos vagy megszeppent állapotot is eredményezhet nála. Különösen akkor, ha még várakoznia is kell a tárgyalóterem előtti folyosón, ahol feltehetően lát megbilincselt, tárgyalásukra váró terhelteket. A tárgyalóteremben pedig a pulpitus közepén egy talárba öltözött személy - a bíró - várja. Ez mind a gyermek számára teljesen szokatlan és idegen környezet, ahol csak egy ismerős személy van vele, a törvényes képviselöje vagy gondozója.

Fel tud-e oldódni ebben az ismeretlen közegben a gyermek, mennyire képes egy tizennegyedik életévét be nem töltött gyermek magától, rásegítő kérdések nélkül elmondani, hogy mi történt vele? Hiszen mindenképpen szükséges a bírónak és az ügyésznek olyan válaszokat adnia, melyböl kiderül, hogy mi volt a sérelmére elkövetett büncselekmény. Ezekben az esetekben legjobb a megértő, jóindulatú, nyugodt határozott magatartás tanúsítása a gyermekkorú tanúval szemben.

Álláspontom szerint a törvényes képviselőnek és a szülőnek is rendkívül nagy a felelőssége. Amikor megindul a büntetőeljárás pszichésen és mentálisan is segítségre fog szorulni a gyermek. A gyermekkorú tanúk még lehet, hogy nem minden részletet jegyeznek meg, lehet, hogy nem volt számukra fontos az a momentum vagy részlet, mely a nyomozást elöre vihetné vagy az elkövetö felelősségre vonásában segítene.

Befolyásolhatja-e az a vallomást, ha otthon elmondatják vele több ízben a történteket, ha az események feldolgozásában való segítség gyanánt pszichológus szakember segítségét veszik igénybe vagy iskolában, óvodában az pedagógusok is az események megismerésére törekednek.

Véleményem szerint ezek mind olyan tényezők, melyek a gyermekkorú tanút befolyásolják a történtekre való visszaemlékezésben. A tizennegyedik életévüket be nem töltött személyek pszichológiai jellemzőit figyelembe véve tartani lehet attól, hogyha több alkalommal elismételtetik velük a történteket, akkor saját maguk is hozzá „költhetnek” történéseket, lehetséges, hogy egyes mozzanatok új köntöst kapnak. Elképzelhető a gondozó, természetesen csak a gyermeknek ,jót akarva" begyakoroltatja vele, hogy milyen szófordulatokat használjon majd a nyomozási bíró elötti kihallgatása alkalmával. Ez természetesen nem jó. A gyermek a felnőttnek kétely nélkül hisz, a tőle hallottakat kritika nélkül elfogadja, és a gyermeket különösen befolyásolhatják szülei, hozzá közel álló felnőttek, de még a játszótársai is. ${ }^{10}$ Arra kellene törekedni, hogy amint a nyomozó hatóság tudomást szerez a gyermek sérelmére elkövetett büncselekményröl, soron kívül történjen meg a kihallgatás, mert ezzel számos, a vallomást befolyásolható tényező kiküszöbölhetővé válhatna.

Bár lehet, hogy a szülő segítő szándékkal, akár akaratlanul is befolyásolja gyermekét a kihallgatása előtt. Játékot, csokit, cukorkát ígérve próbálja rávenni őt arra, ha jól felel a bent elhangzott kérdésekre. Ennek mi lehet a következménye? A gyermekkorú tanú olyanra is megpróbál választ adni, melyre nem tudja a választ ahelyett, hogy helyesen „,nem tudom” feleletet adna az őt kérdező nyomozási bírónak vagy ügyésznek.

Mindezek mellett a nyomozási bíró és az ügyész is befolyásolhatja a gyermekkorú tanút, magával a kérdésfeltevéssel is. Nem könnyü megtalálni azt a szó- és hangsúlyhasználatot ezekkel a tanúkkal szemben, mely egyrészt nem ijeszti meg, másrészt a kérdésekre olyan választ tud adni, mely nem befolyásolt. Gyakran elkövethető hiba többször elmondatni vele a történteket vagy egy-egy részletet kiragadva bele-bele kérdezni a történtekbe, megakasztva a folyamatos elmondását. Ha több alkalommal ismételtetik el a gyerekkel a történteket, előbb-utóbb rá fog jönni, hogy mit akarnak hallani tőle, és ilyen tartalmú feleleteket fog adni kérdezőjének. Kerülni kell a helytelen kérdezéstaktikát, azt, hogy a gyermeket meg-megakasztva próbáljuk rábírni arra - mondván mi már úgyis tudjuk a helyes választ és, hogy mi történt -, hogy irányításunk alatt mondja el a történteket. A gyermekek - életkorukból adódóan is - általában keveset mondanak az őt ért sérelmekről. Azonban Agatha Christie fenti idézetéből is jól látszik, hogy ennek ellenére sokat tudnak, számos olyat is megfigyelnek, melyek a felnőttek számára érdektelennek tünhetnek. Kérdezhetünk tőlük, de 
csak óvatosan, nehogy úgy érezzék, hogy mindenáron meg akarjanak felelni és ki fog derülni, hogy sok gyermekböl válik igen jó tanú.

Szorongásaikat fel is lehet oldani, megtalálva még a tárgyalóteremben is azt a miliőt, melyben biztonságban érezhetik magukat. Akár olyan formában, hogy az ülés összes részt vevője egy körben ülve beszélget, melynek során a gyermek teljesen feloldódhat kérdezőjével közös hobbit találva indulhat el olyan kapcsolat kialakítása, melynek során a gyermek adekvát válaszokat fog adni.

Összefoglalva az eddigieket elmondhatjuk, hogy a gyermekek kihallgatása során figyelembe kell venni, hogy befolyásoló hatású lehet a gyermeknek az a vágya is, hogy megfeleljen másoknak, így akár a szülőknek vagy a kihallgatónak, ami eredményezhet nem helytálló kijelentést. ${ }^{11}$

További garanciális szabályozás a Be. keretén belül, hogy ebben az esetben a gyanúsítottat és a védőt csak utólag kell értesíteni azzal, hogy a kihallgatásról készült jegyzőkönyvet az ügyésznél lehet megtekinteni. ${ }^{12}$

Kiindulva a Be. 231. § (4) bekezdéséböl, mely alapján a nyomozási bíró - indítványra - elrendelheti a tanú kihallgatásának kép- vagy hangfelvevővel, illetve egyéb berendezéssel történő rögzítését ez felvetheti akár annak a lehetőségét is, hogy az ilyen tanúkat ne a tárgyalóteremben hallgassa ki a bíróság, hanem egy olyan közegben, ahol biztonságban érezhetik magukat. Akár otthonában vagy egy olyan helyiségben ahol számára kedves tárgyaival van körülvéve.

Ebben az esetben azonban már a tárgyalásra nem idézhető. Ez alól egy kivétel tehető, ha a tanú a tárgyalás időpontjában a tizennegyedik életévét betöltötte, de akkor is csak különösen indokolt esetben. $^{13}$

Érdekes kérdés merül fel abban az esetben, ha a tárgyalás időpontjában tizennegyedik életévét be nem töltött személyt, akit a nyomozás során a bíróság tanúként nem hallgatott ki, de tanúkénti kihallgatása szükségessé vált, mi a teendő. Ekkor a törvény úgy rendelkezik, hogy a kiküldött bíró vagy megkeresett bíróság útján kell őt kihallgatni. ${ }^{14}$

Álláspontom szerint ekkor is felmerül a gyermekkorú tanú befolyásolhatósága. Mennyire mentesíthető a gyermek ezen típusú kihallgatása alkalmával a befolyásoló tényezőktől? A törvény ebben az esetben kiküldött vagy megkeresett bíró előtti meghallgatást ír elő. Számos esetben előfordulhat olyan, hogy azonos illetékességi területen eljáró bíróságnak kell lefolytatni a tárgyalást és a gyermekkorú tanú kihallgatását elvégezni. A tárgyalás lefolytatása során kérdésként merül fel, hogy milyen módon célszerü ebben az esetben a gyermekkorú tanú kihallgatása. A tárgyalás lefolytatásának gördülékenysége érdekében indokolt lehet akár a tárgyalással azonos időpontra kitüzni a gyermek meghallgatását. Mennyire lehetséges a tanú elkülönítése a szintén a tárgyalásra várakozó akár vádlottak, akár azok hozzátartozóinak már a csak a látványától is?

A Be. lehetőséget ad arra is, hogy a tizennegyedik életévét be nem töltött személyt szembesítsék, de csak abban az esetben, ha a szembesítés benne nem kelt félelmet. ${ }^{15}$ Meg kell értetni a gyermekkorú tanúval azt is, ha úgy gondolja, és nem szeretné elmondani a vele történteket, akkor ezt is megteheti. Nem kell úgy éreznie, hogy a gondozója vagy törvényes képviselője kérését kell mindenképpen teljesítenie.

Az elmúlt évek sajnálatos tapasztalata, bírói gyakorlata azt igazolja, hogy egyre növekszik a gyermekkorú sértettek sérelmére elkövetett erőszakos cselekménye száma és nem mellőzhető a gyermekkorúak vallomásának figyelembe vétele sem.

Az új Be. törekedett a gyermekkorúak kihallgatásával kapcsolatos garanciális szabályok kiépítésére, azonban álláspontom szerint ez még korántsem teljes és további kimunkálást igényelne a jogalkotóktól. Célszerübb lenne egy olyan „intim” környezet lehetőségének a megteremtésére való törekvés, melynek során a gyermekkorú tanú kihallgatása alkalmával még a kétely lehetősége sem merül fel befolyásolhatóságára, félelemkeltésére.

Természetesen a fentiek csak kis szeletét képezik a gyermekkorú tanúk kihallgatása kérdéskörének, azonban mindenképpen el lehetne gondolkodni egy részletesebb és a gyermekek érdekeit jobban szem előtt tartó olyan eljárásjogi szabályozáson, mely a fentebb kifejtett kételyeket, ha nem is mellőzhetik, de minimum szintre csökkenthetik. 


\footnotetext{
${ }^{1}$ Bírósági tikár, Debreceni Városi Bíróság 2 Be. 86. § (1) bekezdés

3 Elek Balázs: A tanú vallomásának befolyásolhatósága a büntetőeljárásban 75-80. old.

4 Bányai-Dredán Dóra pszichológus, családterapeuta: Gyermekkorú áldozat meghallgatásának pszichológiai szempontjai. Az előadás elhangzott a Bírónők Egyesülete és az Eötvös Károly Intézet 2009. december 11-i konferenciáján.

${ }^{5}$ A gyermekkor kérdése természetesen a büntetőjogon belül más relációban is felmerül, lásd például Madai Sándor: A csalás büntetőjogi értékelése, HVG ORAC, Budapest, 2011, 108-112. o.

6 Ibolya Tibor: Kihallgatási taktika a nyomozásban /http://ibolyatibor.atw.hu/Sajat/3.pdf/

7 Kulcsár Gabriella-Pásztor Attila: A gyermek tanúvallomások információtartalmának torzulási lehetőségei. Rendészeti Szemle. 2007/5 97.o.

8 Csehné Varga Gabriella: A tanú kihallgatásának taktikája a nyomozásban. Ügyészségi Értesítő 1977. évi 4. szám 9 Be. 207. § (4) bekezdés

10 Elek Balázs: A tanú vallomásának befolyásolhatósága a büntetőeljárásban 75-80. old.

11 Orosházi Józsefné: Pszichológus szakértő a rendőrség munkájában. Belügyi Szemle 2004/6. szám 20-26. old.

12 Be. 213. § (3) bekezdés

13 Be. 280. § (1) bekezdés

14 Be. 280 . § (2) bekezdés

15 Be. 124. § (3) bekezdés
} 